\title{
Article \\ Financial Risk Management for Sustainable Agricultural Development Based on Corporate Social Responsibility in the Interests of Food Security
}

\author{
Andrey A. Polukhin * and Veronika I. Panarina $\mathbb{D}$
}

Citation: Polukhin, Andrey A., and Veronika I. Panarina. 2022. Financial Risk Management for Sustainable Agricultural Development Based on Corporate Social Responsibility in the Interests of Food Security. Risks 10: 17. https://doi.org/10.3390/risks 10010017

Academic Editor: Wing-Keung Wong

Received: 7 November 2021

Accepted: 20 December 2021

Published: 10 January 2022

Publisher's Note: MDPI stays neutral with regard to jurisdictional claims in published maps and institutional affiliations.

Copyright: (C) 2022 by the authors. Licensee MDPI, Basel, Switzerland. This article is an open access article distributed under the terms and conditions of the Creative Commons Attribution (CC BY) license (https:// creativecommons.org/licenses/by/ $4.0 /)$.
Federal Scientific Center of Legumes and Groat Crops, Federal State Budgetary Scientific Institution, 10/1, Molodezhnaya St., Streletsky, 302502 Oryol, Orel Region, Russia; soyssc@vniizbk.ru

* Correspondence: office@vniizbk.orel.ru

\begin{abstract}
This paper focuses on the problem of the high financial risks of agricultural entrepreneurship, which hinder the sustainable development of agriculture and do not provide food security. This problem is especially topical in the conditions of the COVID-19 crisis when financial risks are urgent. The research basis is the theory of financial risks of entrepreneurship. This paper's RQ is as follows: how should financial risks for the sustainable development of agriculture be managed for the provision of food security? The purpose of this paper is to find ways of managing the financial risks of agricultural entrepreneurship based on its corporate social responsibility for sustainable development and the provision of food security. The contribution to the literature is that the authors offer a solution to the problem of the financial risks of agricultural entrepreneurship. The originality of this paper is that the solution is corporate social responsibility. The universal character of the paper is due to the description of the international experience of corporate social responsibility and proving the contribution of this responsibility for the sustainable development of agriculture and food security as well as its demonstration-based on the case experience of modern Russia of specific, effective, and perspective practices of corporate social responsibility that make a significant contribution to the sustainable development of agriculture and food security. The results are very important for decision making in managing the financial risks of agricultural entrepreneurship.
\end{abstract}

Keywords: agricultural sustainable development; food security; financial risk management; corporate social responsibility

\section{Introduction}

In the context of the COVID-19 pandemic and crisis, as well as under the influence of the global growth in demand for food, the problem of sustainable agricultural development has now become highly relevant (Kang et al. 2021; Molitor et al. 2021). The solution to this problem presupposes highly effective financial risk management, which largely determines the sustainability of agricultural development. Among these risks is a change in average food costs, which reduces the effective demand for agricultural products. Financial risks also include a decrease in agricultural import tariffs, leading to increased competition in agricultural markets.

Another risk is associated with funding for food safety net programs, an increase in which implies an increase in the costs of agricultural enterprises for quality control, and a decrease in which may lead to a decrease in food security. It should also be noted that the risks of a shortage of financial resources for agricultural entrepreneurship can be due to a decrease in the following: access to finance and financial products for farmers, access to diversified financial products, and access to market data and mobile banking.

The problem is that high financial risks, which have grown especially in crisis conditions (in particular, amid the COVID-19 crisis), hinder the sustainable development of agriculture and do not provide food security (Zhu et al. 2021). Thus, it is important to 
search for ways of reducing the financial risks of agricultural entrepreneurship. This paper tries to solve this problem and ensure the sustainable development of agriculture and food security.

The existing literature pays quite a lot of attention to the financial risks of agricultural sustainable development (Tong and Yang 2021; Vavrek et al. 2021). However, the knowledge gap is the uncertainty about how to manage these risks. This raises the research question of this article: how should the financial risks for sustainable agricultural development be managed in the interests of food security? (Belhadi et al. 2021; Oubraham et al. 2021). Existing publications (Hajdu et al. 2021; Budiasa 2020) highlight the important role of the corporate social responsibility of agricultural enterprises in ensuring food security. Based on this, the paper puts forward the following hypothesis: corporate social responsibility must play a key role in managing financial risks for sustainable agricultural development in the interests of food security. The purpose of this paper is to find ways of managing the financial risks of agricultural entrepreneurship based on its corporate social responsibility for sustainable development and the provision of food security.

Based on the foregoing, this article aims to determine the prospects of financial risk management for sustainable agricultural development based on corporate social responsibility in the interests of food security. This goal determined the logical structure of this study. This introduction is followed by a literature review, materials, and research methodology. Then the results are described, including (1) trends in the development of seed production in Russia in the context of ensuring food security and (2) modeling financial risk management for sustainable agricultural development based on corporate social responsibility in the interests of food security. In the conclusion, the results of the study are summarized. The research methodology combines a qualitative method-regression modeling of the influence of corporate social responsibility on financial risks and the sustainability of agriculture and food security - and qualitative cases method, which is used to study Russia's experience and to determine the effective measures of the risk management of agricultural entrepreneurship based on corporate social responsibility for sustainable development and food security.

The contribution of this paper to the literature is as follows: the authors offer a solution to the problem of the financial risks of agricultural entrepreneurship. The originality of this paper is that the solution is corporate social responsibility. The paper's uniqueness is due to the description of the international experience of corporate social responsibility and proving the contribution of this responsibility for the sustainable development of agriculture and food security as well as its demonstration - based on the case experience of modern Russia of specific, effective, and perspective practices of corporate social responsibility that make a significant contribution to the sustainable development of agriculture and food security.

\section{Literature Review}

This paper uses the theory of financial risks of entrepreneurship, whose framework was formulated in Qian and Olsen (2021), Wang et al. (2020), and Zhang (2020). The subject sphere of this research is the financial risk management of agricultural entrepreneurship. The research question of this paper $(\mathrm{RQ})$ is formulated in the following manner: how should financial risks for the sustainable development of agriculture be managed for the provision of food security?

The existing literature describes and notes a high level of financial risks of agriculture. Thus, Frascarelli et al. (2021) proposed the use of an income insurance policy as a new instrument to cover risks in agriculture. Volkenand et al. (2021) noted that the significant risks are the prices and market reflexivity in agricultural future contracts with different maturities. Mojtahedi et al. (2020) demonstrated the transfer of financial risks along the value chain using the example of the Iranian food industry.

The existing literature also emphasizes the vivid negative impact of financial risks on the sustainable development of agriculture and food security. Szczepankiewicz (2021) identified business continuity risks in corporate social responsibility and integrated reports 
of Polish companies. Mukhopadhyay et al. (2021) noted that soil salinization in the face of climate change poses new challenges for sustainable agriculture and food security. Pawlak and Kołodziejczak (2020) proved the key role of agriculture in providing food security in developing countries and provided the rationale in the context of the problem of sustainable food production.

The performed literature review demonstrated a reliable theoretical basis for this study but revealed a gap in the available literature, consisting of the uncertainty of the prospects and underdevelopment of the scientific methodology of managing the financial risks of agricultural entrepreneurship. The existing literature vividly shows the necessity to manage financial risks in agriculture but does not suggest any effective measures for this management. That is why there is a need for further elaboration on the selected subject sphere-financial risk management of agricultural entrepreneurship —which is aimed at the development of specific scientific, methodological, and applied recommendations, which is done in this paper.

This paper's hypothesis $\left(H_{0}\right)$ is as follows: corporate social responsibility must play a key role in managing financial risks for sustainable agricultural development in the interests of food security. The basis of suggesting such a hypothesis is the existing literature (Grabs and Carodenuto 2021; Svitacova 2021; Tang et al. 2021), which notes the clearly expressed advantages of corporate social responsibility for the sustainable development of agricultural entrepreneurship.

Thus, Popkova et al. (2020) noted the complexity of the manifestation of corporate social responsibility against the background of social distancing during the COVID-19 crisis in the example of the BRICS and OECD countries. Popkova and Sergi (2021) outlined the paths to the development of social entrepreneurship in Russia and the countries of Central Asia. Graddy-Lovelace (2021) proposed the development of the responsibility of farmers and non-agricultural enterprises to each other through the example of negotiating social contracts and the public good of agriculture. De Olde and Valentinov (2019) highlighted the moral complexity of agriculture concerning the challenges of corporate social responsibility.

A gap analysis of the existing literature has shown that the contribution of corporate social responsibility to financial risk management is poorly studied. Due to its noncommercial essence, corporate social responsibility is treated in the existing literature as a source of only non-financial advantages in agricultural entrepreneurship. The commercial potential of corporate social responsibility in agriculture, which consists of the reduction of financial risks, is poorly studied and not determined.

This article intends to fill the gap through the verification of the suggested hypothesis that corporate social responsibility in agriculture contributes to sustainable development and food security through the reduction of the financial risks of agricultural entrepreneurship. This paper is to shed light on a new, financial aspect of corporate social responsibility with regards to agricultural entrepreneurship.

\section{Methodology}

To check the hypothesis, the authors model financial risk management for sustainable agricultural development based on corporate social responsibility in the interests of food security. For this, the authors use the methodology of regression analysis, the choice of which is explained by its high accuracy and reliability. The advantage of using the method of regression analysis in this paper, as opposed to alternative methods, is the possibility to determine correct and precise quantitative connections between the statistics of corporate social responsibility and the statistics of financial risks of agricultural entrepreneurship, as well as to measure-with high precision-the corporate social responsibility's effect on the sustainability of agriculture and food security.

To obtain reliable results reflecting the situation in the global economy as a whole, the research is performed based on a sample of 86 countries (Appendix A Table A1), the data on which could be found in the materials of the Charities Aid Foundation (2021) and The Economist Intelligence Unit Limited (2021). 
To test the hypothesis $H_{0}$ put forward, a regression analysis is carried out:

1. The dependence of food security indicators (according to the materials of The Economist Intelligence Unit Limited (2021)) on the financial risks in agriculture (according to the materials of The Economist Intelligence Unit Limited (2021));

2. The dependence of the selected key financial risks in agriculture on the World Giving Index (according to the materials of the Charities Aid Foundation (2021)).

Statistics of financial risks in agriculture include the following:

- $\quad$ Change in average food costs (fc);

- Agricultural import tariffs (it);

- $\quad$ Funding for food safety net programmes (fs);

- $\quad$ Access to finance and financial products for farmers (fp);

- Access to diversified financial products for farmers (df);

- Access to market data and mobile banking (mb).

Food security statistics include the following:

- $\quad$ Affordability $\left(\mathrm{FS}_{1}\right)$;

- Availability $\left(\mathrm{FS}_{2}\right)$;

- Quality and safety $\left(\mathrm{FS}_{3}\right)$;

- Natural resources and resilience $\left(\mathrm{FS}_{4}\right)$.

The World Giving Index is denoted here as gi. The empirical data for studying the international experience for 2021 are given in the supplementary table. The following research model is used:

$$
\left\{\begin{array}{c}
\mathrm{FS}_{i}=\alpha_{i}+\beta_{i 1} \times \mathrm{fc}+\beta_{i 2} \times \mathrm{it}+\beta_{i 3} \times \mathrm{fs}+\beta_{i 4} \times \mathrm{ffp} \beta_{i 5} \times \mathrm{df}+\beta_{i 6} \times \mathrm{mb} ; \\
\mathrm{fc}=\alpha_{f c}+\beta_{f c} \times \mathrm{gi} ; \\
\mathrm{it}=\alpha_{i t}+\beta_{i t} \times \mathrm{gi} ; \\
\mathrm{fs}=\alpha_{f s}+\beta_{f s} \times \mathrm{gi} ; \\
\mathrm{fp}=\alpha_{f p}+\beta_{f p} \times \mathrm{gi} ; \\
\mathrm{df}=\alpha_{d f}+\beta_{d f} \times \mathrm{gi} ; \\
\mathrm{mb}=\alpha_{m b}+\beta_{m b} \times \mathrm{gi} ;
\end{array}\right.
$$

To check the reliability of the regression equations in research model (1), Fisher's F-test is used $\left(\mathrm{F}_{\mathrm{obs}}\right.$ must be greater than $\left.\mathrm{F}_{\mathrm{tabl}}\right)$ and the significance of $\mathrm{F}$ is measured (must be less than 0.05). Additionally, the authors study the indicators of the Variance Inflation Factor (VIF) of each variable to exclude multicollinearity and spurious regression.

Due to the lack of statistics directly characterizing corporate social responsibility, in this article, the World Giving Index is chosen as a reflecting indicator of corporate social responsibility.

The method of regression analysis provides arguments during the testing of the offered hypothesis but allows only the generalized, framework recommendations. To develop detailed applied recommendations on the use of corporate social responsibility for the management of financial risks of agricultural entrepreneurship, the authors use a case study method. This method is used to systematize and analyze the case experience of Russia's regions in the practical use of corporate social responsibility for managing the financial risks of agricultural entrepreneurship. This makes it possible to determine the perspective measures and, based on them, offer detailed recommendations.

\section{Results}

4.1. Modeling of the Financial Risk Management for Sustainable Agricultural Development Based on Corporate Social Responsibility in the Interests of Food Security

As a result of modeling financial risk management for sustainable agricultural development in the interests of food security according to research model (1), the following regression equations are obtained: 
- $\mathrm{FS}_{1}=45.003+0.23 \times \mathrm{fs}+0.18 \times \mathrm{df}$. According to the obtained regression equation, with an increase in funding for food safety net programs by $1 \%$, affordability increases by 0.23 points. With a $1 \%$ increase in access to diversified financial products, affordability increases by 0.18 points. $F_{\text {obs }}=124.57$. For 86 observations and 2 variables at a significance level of $0.05 \mathrm{~F}_{\mathrm{tabl}}=4.00$. Since $\mathrm{F}_{\mathrm{obs}}>\mathrm{F}_{\mathrm{tabl}}(124.57>4.00)$, the F-test is passed. Consequently, the obtained equation is reliable at a significance level of 0.05 . The coefficient of multivariable correlation $R^{2}=0.8661$. Variance Inflation Factor $(\mathrm{VIF})$ : VIF $=1 /\left(1-\mathrm{R}^{2}\right)=1 /(1-0.8661)=7.47$. Since VIF does not exceed 10 , multicollinearity is low, and spurious regression is absent.

- $\mathrm{FS}_{2}=50.29+0.13 \times \mathrm{df}$. According to the obtained regression equation, with an increase in access to diversified financial products by $1 \%$, availability increases by 0.13 points. $F_{\text {obs }}=25.22$. For 86 observations and 1 variable at a significance level of $0.05 \mathrm{~F}_{\mathrm{tabl}}=3.15$. Since $\mathrm{F}_{\mathrm{obs}}>\mathrm{F}_{\mathrm{tabl}}(25.22>3.15)$, the F-test is passed. Therefore, the obtained equation is reliable at a significance level of 0.05 . The coefficient of multivariable correlation $\mathrm{R}^{2}=0.4805$. Variance Inflation Factor (VIF): VIF $=1 /(1-$ $\left.\mathrm{R}^{2}\right)=1 /(1-0.4805)=1.92$. Since VIF does not exceed 10 , multicollinearity is low, and spurious regression is absent.

- $\mathrm{FS}_{3}=45.17+0.18 \times$ it $+0.22 \times \mathrm{fs}$. According to the obtained regression equation, with an increase in agricultural import tariffs by $1 \%$, quality and safety increases by 0.18 points. With an increase in funding for food safety net programs by $1 \%$, quality and safety increases by 0.22 points. $F_{\text {obs }}=44.65$. For 86 observations and 2 variables at a significance level of $0.05 \mathrm{~F}_{\mathrm{tabl}}=4.00$. Since $\mathrm{F}_{\mathrm{obs}}>\mathrm{F}_{\mathrm{tabl}}(44.65>4.00)$, the F-test is passed. Therefore, the obtained equation is reliable at a significance level of 0.05 . The coefficient of multivariable correlation $\mathrm{R}^{2}=0.7199$. Variance Inflation Factor (VIF): VIF $=1 /\left(1-R^{2}\right)=1 /(1-0.7199)=3.57$. Since VIF does not exceed 10 , multicollinearity is low, and spurious regression is absent.

- $\quad \mathrm{FS}_{4}=42.56+0.15 \times \mathrm{df}$. According to the obtained regression equation, with an increase in access to diversified financial products by $1 \%$, natural resources and agricultural sustainability increase by 0.15 points. $\mathrm{F}_{\mathrm{obs}}=44.46$. For 86 observations and 1 variable at a significance level of $0.05 \mathrm{~F}_{\mathrm{tabl}}=3.15$. Since $\mathrm{F}_{\mathrm{obs}}<\mathrm{F}_{\mathrm{tabl}}(44.46>3.15)$, the F-test is passed. Therefore, the obtained equation is reliable at a significance level of 0.05 . The coefficient of multivariable correlation $\mathrm{R}^{2}=0.5883$. Variance Inflation Factor (VIF): VIF $=1 /\left(1-R^{2}\right)=1 /(1-0.5883)=2.43$. Since VIF does not exceed 10 , multicollinearity is low, and spurious regression is absent.

The maximum variance inflation factor (VIF) values in each model indicate that multicollinearity is not a significant concern and ranges from 1.92 to 7.47; VIF scores remain below the maximum acceptable level of 10 (Hair et al. 2010) and are even twice less than 5 (Diamantopoulos and Winklhofer 2001).

Thus, three key financial risks of food security have been selected: a decrease in agricultural import tariffs (it), a reduction in funding for food safety net programs (fs), and a decrease in access to diversified financial products (df). The regression curves of the selected financial risks versus corporate social responsibility are shown in Figure 1.

According to Figure 1, an increase in the World Giving Index by $1 \%$ leads to an improvement of agricultural import tariffs by 0.212 points. This suggests-as a framework recommendation-increasing the World Giving Index by $180.50 \%$, up to $100 \%$. The results of implementing the suggested recommendations for sustainable agriculture and food security are given in Figure 2.

According to Figure 2, as a result of the implementation of the author's recommendation, agricultural import tariffs improve by $21.41 \%$ (from 63.70 points to 77.35 points). As a result, food security and quality grow by $3.52 \%$ (from 71.66 points to 74.19 points). 

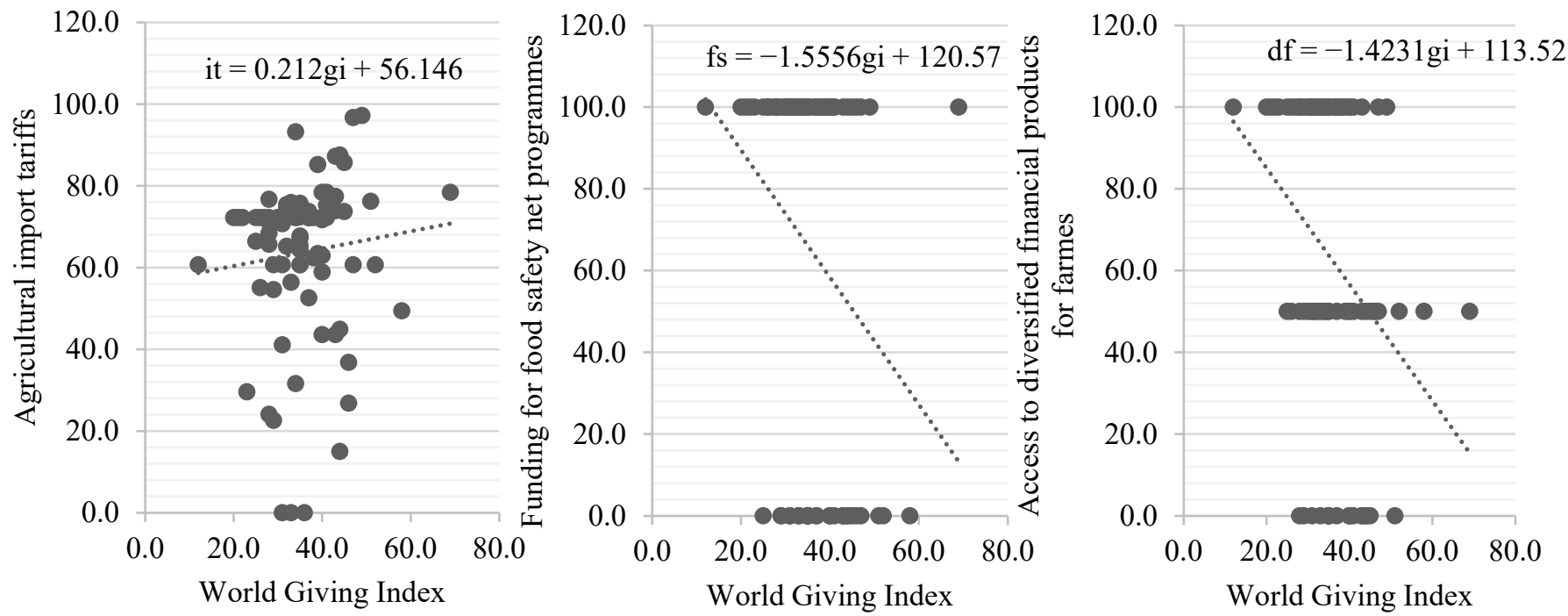

Figure 1. Regression curves of selected financial risks versus corporate social responsibility. Source: Calculated and built by the authors.

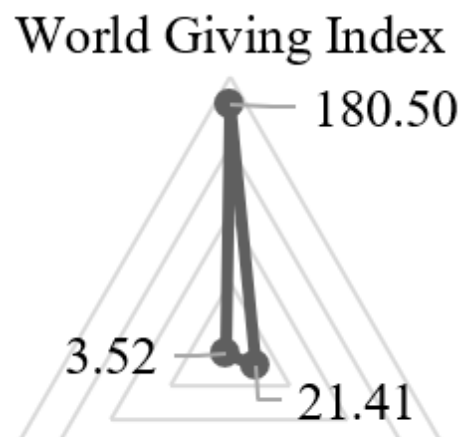

Quality and Safety

\section{Agricultural import} tariffs

Figure 2. Sustainable agriculture and food security growth due to financial risk management based on corporate social responsibility (compared to 2021), \%. Source: Calculated and built by the authors.

\subsection{Seed Production Development Trends in Russia in the Context of Food Security}

To supplement and specify the developed framework recommendation, let us systematize and analyze the case experience of Russia's regions in the practical use of corporate social responsibility for managing the financial risks of agricultural entrepreneurship.

The agro-industrial complex of Russia is, first of all, composed of separate territories (regions) and the dynamics of their development on which its economic efficiency depends. Most regions are actively working to create a positive image or regional brand of a particular product, increase entrepreneurial activity, and intensify the investment flows. The regional agrarian sector is a special socio-economic system that combines the features of a territorial cluster with a simultaneously developed sectoral type of management, which makes it possible to develop common approaches to solving the problems currently present in most agricultural business entities (Ter-Grigoryants 2010).

The development of regional agriculture without state support in solving some problems becomes difficult, and taking into account the accumulated experience, this system will become more effective over the years. It is no less important that the receipt of agricultural products is closely interconnected with the natural and climatic conditions of the regions, which makes it possible to single out the specialization in the production of crops for each of them. In addition, a large share of regional land designated for the cultivation 
of crops is in the possession of large agricultural holdings, leaving virtually no opportunity for the development of small economic entities.

It is necessary to approach the development of regional agriculture considering not only the existing groundwork but also paying special attention to planning, taking into account the specifics of each region of Russia. Management decisions will become more effective if they are made taking into account the current and possible future states of the balance of the system, and the indicators of retrospective development should be used to construct variable development trends (Laskov 2008). Therefore, there is, first of all, the need to determine the prior specificity of the regions in the crop production industry.

The leaders among the Federal Districts in terms of acreage in Russia are the Volga, Central, Siberian, and Southern Federal Districts-they account for 30.0\%, 19.9\%, 17.7\%, and $16.6 \%$, respectively, of the total acreage in the Russian Federation. The regions in the top 10 by acreage are Rostov Region, Krasnodar Territory, Volgograd, Voronezh, Tambov, Kursk, Belgorod, Lipetsk, Orel, and Ryazan Regions (Table 1).

Table 1. Leading regions in the acreage of crops in the Russian Federation, 2020.

\begin{tabular}{ccc}
\hline Region & $\begin{array}{c}\text { Share in the Total Structure } \\
\text { of Acreage, } \%\end{array}$ & Acreage, Thousand Ha. \\
\hline Rostov Region & 5.9 & 4748.0 \\
Krasnodar Territory & 4.7 & 3727.2 \\
Volgograd Region & 3.9 & 3090.9 \\
Voronezh Region & 3.4 & 2685.9 \\
Tambov Region & 2.3 & 1831.1 \\
Kursk Region & 2.1 & 1666.3 \\
Belgorod Region & 1.8 & 1425.2 \\
Lipetsk Region & 1.7 & 1372.6 \\
Orel Region & 1.6 & 1313.2 \\
Ryazan Region & 1.3 & 1020.4 \\
\hline
\end{tabular}

Source: Calculated by the authors based on Rosstat data (Rosstat 2021a).

The main crops cultivated in the Russian Federation are cereals and legumes (they account for $59.0 \%$ of the total acreage), forage and technical crops (19.0\% each), and potatoes, vegetables, and melons (about 2.5\%) (Table 2).

Table 2. Dynamics of the share of the main groups of crops in the acreage structure in the Russian Federation, 2016-2020.

\begin{tabular}{cccccc}
\hline Crops & $\mathbf{2 0 1 6}$ & $\mathbf{2 0 1 7}$ & $\mathbf{2 0 1 8}$ & $\mathbf{2 0 1 9}$ & $\mathbf{2 0 2 0}$ \\
\hline Cereals and legumes & 59.4 & 59.6 & 58.2 & 58.4 & 59.9 \\
Industrial & 17.2 & 17.4 & 19.1 & 19.9 & 19.4 \\
Potatoes, vegetables, and melons & 2.7 & 2.6 & 2.5 & 2.4 & 2.3 \\
Forage & 20.7 & 20.4 & 20.2 & 19.3 & 18.5 \\
Total & 100.0 & 100.0 & 100.0 & 100.0 & 100.0 \\
\hline
\end{tabular}

Source: Calculated by the authors based on Rosstat data (Rosstat 2021a).

A more detailed study of the crops cultivated in the country made it possible to identify 12 main crops, such as winter and spring wheat whose share is $19.3 \%$ and $15.9 \%$, respectively; sunflower for grain at $10.3 \%$; spring barley at $9.8 \%$; corn for grain maize and green maize at $5.1 \%$; oats and soybeans at $3.4 \%$ each; rapeseed at $1.7 \%$; peas and potatoes at $1.6 \%$ each; and buckwheat and sugar beet at $1.4 \%$ each (Figure 2 ).

Considering the main crops identified as a result of the analysis in the context of regionleaders in gross yield, a clear specialization of some regions according to the priorities of crop production is revealed (Table 3): 
1. Rostov Region-winter wheat, sunflower for grain, spring barley, and grain maize;

2. Krasnodar Territory-winter wheat, grain maize, peas, sugar beet, sunflower for grain, and soybeans;

3. Altay Territory—spring wheat, oats, buckwheat and rapeseed, sunflower for grain, soybeans, and peas;

4. Saratov Region-sunflower for grain, winter wheat, and buckwheat;

5. Voronezh Region - spring barley, sugar beet, winter wheat, sunflower for grain, grain maize, soybeans, and potatoes;

6. The Republic of Tatarstan-spring barley, potatoes, oats, rapeseed, peas, buckwheat, and sugar beet;

7. Kursk Region-grain maize, soybeans, sugar beet, winter wheat, spring barley, and buckwheat;

8. Krasnoyarsk Territory-oats, rapeseed, spring wheat, and potatoes;

9. Belgorod Region-soybeans, winter wheat, grain maize, and sugar beet;

10. Amur Region-soybeans;

11. Stavropol Territory-peas, winter wheat, and rapeseed;

12. Bryansk Region-potatoes and grain maize;

13. Orel Region-buckwheat, winter wheat, spring barley, grain maize, soybeans, and sugar beet;

14. The Republic of Bashkortostan-buckwheat, spring wheat, spring barley, oats, peas, potatoes, and sugar beet;

15. Lipetsk Region—sugar beet, sunflower for grain, spring barley, soybeans, and rapeseed.

Table 3. Top 10 regions of the Russian Federation by share in the structure of gross yield of the main crops (\%), 2020.

\begin{tabular}{|c|c|c|c|c|c|}
\hline \multicolumn{2}{|l|}{ Winter Wheat } & \multicolumn{2}{|l|}{ Spring Wheat } & \multicolumn{2}{|c|}{ Sunflower for Grain } \\
\hline Orel Region & 3.54 & Penza Region & 3.41 & Lipetsk Region & 4.13 \\
\hline Belgorod Region & 3.70 & Tyumen Region & 3.52 & Altay Territory & 4.97 \\
\hline Tambov Region & 3.73 & Orenburg Region & 4.06 & Tambov Region & 6.54 \\
\hline Kursk Region & 4.34 & Kurgan Region & 4.69 & Samara Region & 6.72 \\
\hline Saratov Region & 5.50 & Republic of Tatarstan & 5.25 & Orenburg Region & 6.81 \\
\hline Voronezh Region & 5.80 & Republic of Bashkortostan & 5.41 & Krasnodar Territory & 6.92 \\
\hline Stavropol Territory & 6.86 & Novosibirsk Region & 7.22 & Voronezh Region & 7.89 \\
\hline Volgograd Region & 6.91 & Krasnoyarsk Territory & 7.49 & Volgograd Region & 7.99 \\
\hline Krasnodar Territory & 12.32 & Altay Territory & 8.65 & Rostov Region & 10.63 \\
\hline Rostov Region & 16.66 & Omsk Region & 9.52 & Saratov Region & 13.14 \\
\hline \multicolumn{2}{|l|}{ Spring Barley } & \multicolumn{2}{|l|}{ Grain Maize } & \multicolumn{2}{|l|}{ Oat } \\
\hline Samara Region & 3.01 & Rostov Region & 4.01 & Udmurtian Republic & 2.90 \\
\hline Ryazan Region & 3.45 & Orel Region & 4.58 & Kemerovo Region & 3.30 \\
\hline Orel Region & 3.82 & $\begin{array}{l}\text { Republic of North } \\
\text { Ossetia-Alania }\end{array}$ & 5.17 & Omsk Region & 3.42 \\
\hline Rostov Region & 3.85 & Tambov Region & 5.36 & Irkutsk Region & 3.54 \\
\hline Republic of Bashkortostan & 5.10 & Bryansk Region & 6.09 & Tyumen Region & 4.52 \\
\hline Lipetsk Region & 5.38 & Belgorod Region & 6.33 & Republic of Tatarstan & 4.60 \\
\hline Kursk Region & 5.65 & Voronezh Region & 6.59 & Novosibirsk Region & 4.83 \\
\hline Tambov Region & 5.74 & $\begin{array}{l}\text { Kabardino-Balkarian } \\
\text { Republic }\end{array}$ & 6.96 & Republic of Bashkortostan & 6.24 \\
\hline Voronezh Region & 6.29 & Kursk Region & 10.25 & Krasnoyarsk Territory & 8.61 \\
\hline Republic of Tatarstan & 8.34 & Krasnodar Territory & 15.53 & Altay Territory & 8.90 \\
\hline
\end{tabular}


Table 3. Cont.

\begin{tabular}{|c|c|c|c|c|c|}
\hline \multicolumn{2}{|l|}{ Soybean } & \multicolumn{2}{|l|}{ Rapeseed } & \multicolumn{2}{|l|}{ Pea } \\
\hline Lipetsk Region & 2.60 & Lipetsk Region & 4.33 & Tambov Region & 3.97 \\
\hline Altay Territory & 3.96 & Ryazan Region & 4.47 & Ryazan Region & 4.02 \\
\hline Orel Region & 4.38 & Stavropol Territory & 4.49 & Republic of Bashkortostan & 4.41 \\
\hline Voronezh Region & 4.68 & Novosibirsk Region & 4.80 & Republic of Tatarstan & 4.92 \\
\hline Tambov Region & 5.60 & Republic of Tatarstan & 5.17 & Novosibirsk Region & 5.54 \\
\hline Krasnodar Territory & 7.16 & Kemerovo Region & 5.27 & Altay Territory & 5.63 \\
\hline Primorye Territory & 8.75 & Kaliningrad Region & 5.70 & Omsk Region & 5.78 \\
\hline Kursk Region & 12.69 & Tula Region & 6.04 & Krasnodar Territory & 8.35 \\
\hline Belgorod Region & 13.02 & Altay Territory & 7.38 & Rostov Region & 8.72 \\
\hline Amur Region & 22.72 & Krasnoyarsk Territory & 10.50 & Stavropol Territory & 12.20 \\
\hline \multicolumn{2}{|l|}{ Potato } & \multicolumn{2}{|l|}{ Buckwheat } & \multicolumn{2}{|l|}{ Sugar Beet } \\
\hline Moscow Region & 2.28 & Saratov Region & 1.15 & Republic of Bashkortostan & 3.80 \\
\hline Kemerovo Region & 2.32 & Republic of Tatarstan & 1.58 & Belgorod Region & 5.27 \\
\hline Krasnoyarsk Territory & 3.15 & Kursk Region & 2.13 & Orel Region & 5.43 \\
\hline Sverdlovsk Region & 3.50 & Tula Region & 2.29 & Penza Region & 5.54 \\
\hline Tula Region & 3.57 & Orenburg Region & 2.43 & Republic of Tatarstan & 6.34 \\
\hline Republic of Bashkortostan & 3.62 & Kemerovo Region & 3.07 & Tambov Region & 9.48 \\
\hline Voronezh Region & 3.66 & Novosibirsk Region & 4.18 & Lipetsk Region & 10.40 \\
\hline Nizhny Novgorod Region & 3.82 & Republic of Bashkortostan & 7.23 & Voronezh Region & 10.46 \\
\hline Bryansk Region & 5.88 & Orel Region & 8.98 & Kursk Region & 11.54 \\
\hline Republic of Tatarstan & 5.99 & Altay Territory & 55.94 & Krasnodar Territory & 17.25 \\
\hline
\end{tabular}

Source: Calculated by the authors based on Rosstat data (Rosstat 2021b).

For sowing the main crops, Russian agrarians use seeds of spring cereals and leguminous crops of various categories. Of all the seeds used in the sowing campaign, the share of sowing material of the elite category on average for 2017-2020 accounted for 11.3\%, for 1-4 reproductions it was $62.3 \%$ (Figure 3 ). However, there are sharp fluctuations over the years. As a result, in 2017, the share of elite seeds of spring cereals and leguminous crops amounted to $9.9 \%$, then in 2018 and 2019 it was $10.3 \%$ and $11.4 \%$, respectively, and in 2020 it increased to $13.7 \%$. The share of sown seeds of spring cereals and leguminous crops of 1-4 reproductions in the farms of the Russian Federation has also changed. In 2019 and 2020, this value was 63.3\% and 64.6\%, respectively, an increase compared to 2017 and 2018, which amounted to $4.4 \%$ and $6.6 \%$, respectively.

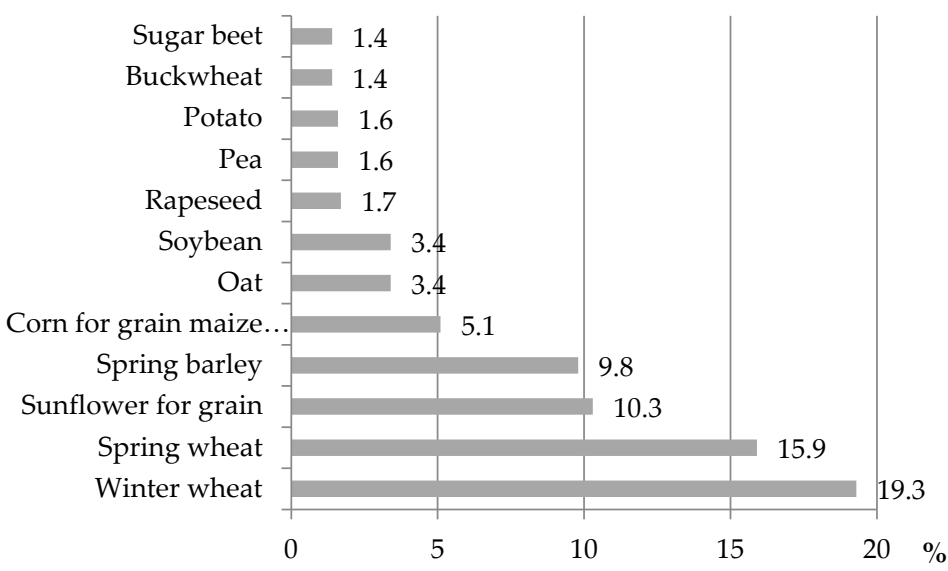

Figure 3. The share of the acreage of the main crops cultivated in the Russian Federation, on average for 2016-2020.

The data from Figure 4 show that the share of elite seeds in the structure of seeds used by Russian agricultural enterprises grows annually. Therefore, transition from regular 
seeds to elite seeds is a perspective measure of corporate social responsibility for managing the financial risks of agricultural entrepreneurship.

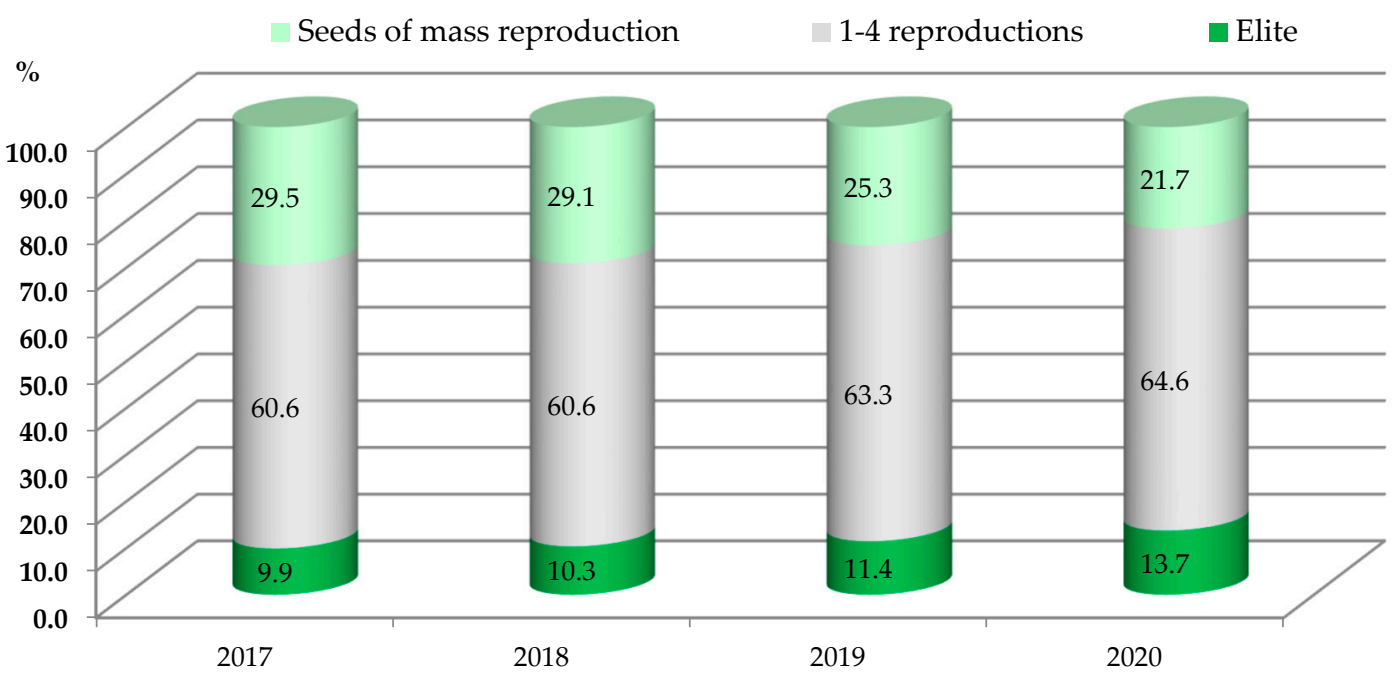

Figure 4. The share of sown seeds of spring cereals and leguminous crops in farms of the Russian Federation by their category in 2017-2020. Source: Calculated by the authors based on data from the Federal State Budgetary Institution Rosselkhoztsentr (2021a, 2021b, 2021c, 2021d).

In the context of Federal Districts, the dynamics of sown seeds of spring cereals and leguminous crops in farms by their category is presented in Table 4 . It can be seen that the volume of seeds sown in the elite category in 2019 decreased in the Central Federal District by 2.6 thousand tons, in the North-western and Southern Federal Districts by 5.4 thousand tons, and in the North Caucasus Federal District by 1.2 thousand tons compared to the previous year. Whereas in the same year in the Volga, Ural, Siberian, and Far Eastern Federal Districts, there was an increase in the volume of sown seeds of the elite category by 38.7, 18.2, 10.1, and 3.6 thousand tons, respectively. Furthermore, in 2020, the volume of sown seeds of the elite category started to increase in all Federal Districts of the Russian Federation.

Such changes are primarily associated with government support in the field of elite seed production. As a result, from 2017 to 2018 subsidies were provided from the federal budget for the purchase of elite seeds within the framework of a "single" subsidy, including for the support of elite seed production for cereals and leguminous crops. However, in 2019, support for seed production by the state was carried out within the framework of unrelated support for agricultural producers, but only for a certain number of crops, excluding cereals and leguminous crops (Korolkova et al. 2020). However, in 2020, new rules for providing a "single" subsidy, consisting of a stimulating and compensating part, came into force, one of the directions of which is to support elite seed production at a rate per 1 hectare of acreage (MCX 2021) (Table 4).

The data from Table 4 show that Russian agricultural enterprises annually increase the level of use of their production capacities. Therefore, the increase in the level of use of production capacities is a perspective measure of corporate social responsibility for managing the financial risks of agricultural entrepreneurship.

To provide agricultural producers with high-quality seed, since 2010 in the Russian Federation, a voluntary certification of seed farms in the "Rosselkhoztsentr" System has been carried out. As of 1 July 2021, it includes 932 farms engaged in seed production of various crops, which is $9.0 \%$ less than at the beginning of 2017 (Polukhin and Panarina 2017). Figure 4 shows the dynamics of the inclusion of seed farms into the register. The largest number of registrations was noted in 2014, 2015, 2019, and 2020, which is primarily due to their re-registration. 
Table 4. Dynamics of sown seeds of spring cereals and leguminous crops in farms of the Russian Federation by their category in 2017-2020, thousand tons.

\begin{tabular}{ccccccccc}
\hline \multirow{2}{*}{ Federal District } & \multicolumn{2}{c}{$\mathbf{2 0 1 7}$} & \multicolumn{2}{c}{$\mathbf{2 0 1 8}$} & \multicolumn{2}{c}{$\mathbf{2 0 1 9}$} & \multicolumn{2}{c}{$\mathbf{2 0 2 0}$} \\
\cline { 2 - 8 } & Elite & $\begin{array}{c}\mathbf{1 - 4} \\
\text { Reproductions }\end{array}$ & Elite & $\begin{array}{c}\mathbf{1 - 4} \\
\text { Reproductions }\end{array}$ & Elite & $\begin{array}{c}\mathbf{1 - 4} \\
\text { Reproductions }\end{array}$ & $\begin{array}{c}\text { Elite } \\
\text { Reproductions }\end{array}$ \\
\hline Central & 59.3 & 560.6 & 59.3 & 574.8 & 56.7 & 616.7 & 62.7 & 618.7 \\
North-western & 12.2 & 40.7 & 13.8 & 36.9 & 8.4 & 40.2 & 9.3 & 42.1 \\
Southern & 25.4 & 212.6 & 28.3 & 248.6 & 22.9 & 199.2 & 24.4 & 178.6 \\
North Caucasus & 3.2 & 53.5 & 3.7 & 64.2 & 2.5 & 62.7 & 3.5 & 60.1 \\
Volga & 200.9 & 1048.0 & 218.1 & 1048.7 & 256.8 & 1066.1 & 309.5 & 999.4 \\
Ural & 71.4 & 412.9 & 67.2 & 390.9 & 85.4 & 418.5 & 103.2 & 463.9 \\
Siberian & 157.3 & 968.0 & 177.0 & 969.1 & 187.1 & 1015.6 & 213.9 & 1088.6 \\
Far Eastern & 11.8 & 35.6 & 5.8 & 46.9 & 9.4 & 61.8 & 16.9 & 59.5 \\
\hline
\end{tabular}

Source: Calculated by the authors based on data from the Federal State Budgetary Institution Rosselkhoztsentr (2021a, 2021b, 2021c, 2021d).

The data from Figure 5 show that the level of voluntary certification registration of products by Russian agricultural enterprises grows annually. Therefore, voluntary certification of quality is a perspective measure of corporate social responsibility for managing the financial risks of agricultural entrepreneurship. In the structure of seed farms registered in the "Rosselkhoztsentr" voluntary certification system, commercial organizations prevail at $73.3 \%$, state entities account for $18.7 \%$, and small business entities $8.0 \%$ (Figures 5 and 6 ).

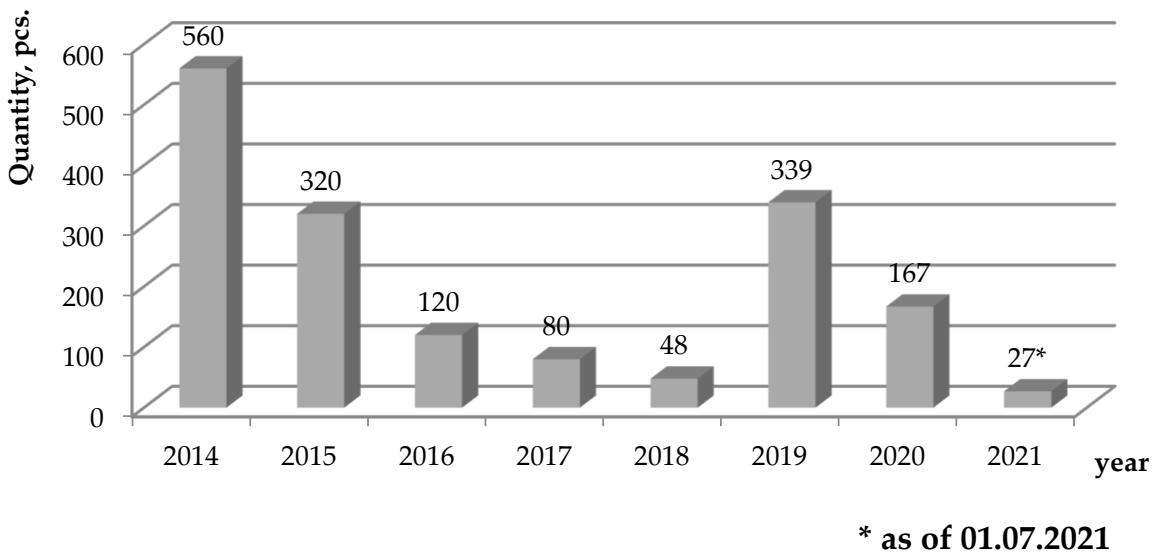

Figure 5. Dynamics of seed farms' registration in the voluntary certification system "Rosselkhoztsentr". Source: Calculated by the authors based on data from the Federal State Budgetary Institution Rosselkhoztsentr (2021d).

Thus, the main producers of the highest reproduction seeds are large organizations that have the necessary material and technical bases to obtain high-quality seed-growing material, staff, and financial and economic freedom to manage funds and use state support. The following perspective measures of corporate social responsibility for managing the financial risks of agricultural entrepreneurship are suggested:

- Transition from regular seeds to elite seeds;

- Increase in the use of production capacities;

- Voluntary certification of quality. 


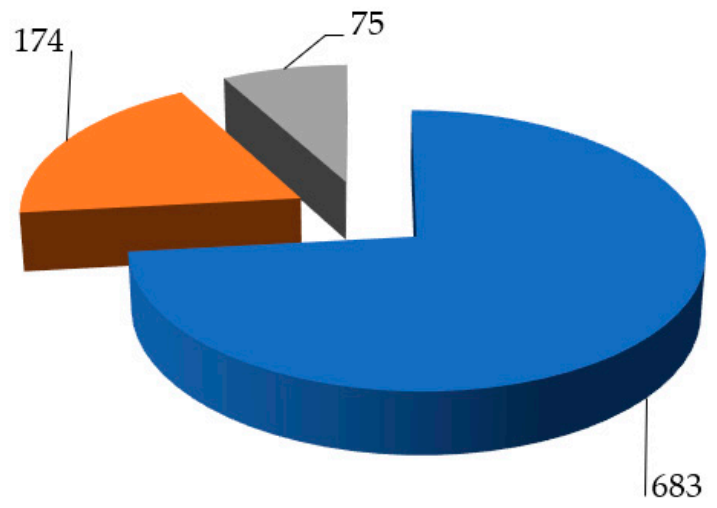

Commercial organizations

Small business entities

State entities

Figure 6. Structure of seed farms in the "Rosselkhoztsentr" voluntary certification system by the organizational form for the first half of 2021. Source: Calculated by the authors based on data from the Federal State Budgetary Institution Rosselkhoztsentr (2021c).

\section{Discussion}

This paper develops and expands the theory of financial risks of entrepreneurship. Unlike the existing literature on the topic of financial risks of agricultural entrepreneurship (in particular, the works of Qian and Olsen 2021; Wang et al. 2020; and Zhang 2020), this paper undertakes, for the first time, the transition from description of risks to their management and outlines the prospects of financial risk management in agriculture. An answer to the research question (RQ) has been found - the management of financial risks for sustainable development of agriculture for the provision of food security should be performed through corporate social responsibility.

Unlike the existing literature (Grabs and Carodenuto 2021; Svitacova 2021; Tang et al. 2021), this paper proves that the advantages of corporate social responsibility for the sustainable development of agricultural entrepreneurship are not limited by the nonfinancial benefits of agricultural entrepreneurship, but also include the reduction of financial risks. A rather large commercial potential of corporate social responsibility in agriculture has been determined-it consists of the reduction of financial risks. Based on the given arguments, the hypothesis $H_{0}$ has been proved; it has also been substantiated that corporate social responsibility must play a key role in managing financial risks for sustainable agricultural development in the interests of food security. Due to this, the paper sheds light on a new, financial aspect of corporate social responsibility in respect of agricultural entrepreneurship.

\section{Conclusions}

The main purpose of this research is to study the perspectives of financial risk management of agricultural entrepreneurship and to shed light on new perspectives using corporate social responsibility to reduce the financial risks in agriculture. Regression analysis has been used for the modeling of the impact of corporate social responsibility on financial risks in agriculture and food security.

Summing up the above, it should be concluded that the suggested hypothesis has been proved. The modeling of financial risk management for sustainable agricultural development, based on corporate social responsibility in the interests of food security using the method of regression analysis, has shown that food security (affordability and availability, quality and safety) is determined by three key financial risks of agricultural sustainable development: the decrease in agricultural import tariffs, the decrease in funding for food safety net programmes, and the decrease in access to diversified financial products.

The authors have discovered that social responsibility determines agricultural import tariffs, thus increasing food quality and security. It has been established that at the maximum possible level of corporate social responsibility, food quality and security could grow by $3.52 \%$. 
The advantage of this work lies in the following: First, it offers a perspective approach to managing the financial risks in agricultural entrepreneurship, which is based on corporate social responsibility. Second, a close connection between corporate social responsibility and sustainable agriculture and food security has been proved. The results are very important for decision making in managing the financial risks of agricultural entrepreneurship.

Practical recommendations (based on the study of Russia's case experience) for managing the financial risks in agricultural entrepreneurship and increasing food security and quality (as a manifestation of the sustainability of agriculture and food security) include the transition from regular seeds to elite seeds, increase of the use of production capacities, and voluntary certification of quality.

A limitation of the obtained results is that the suggested recommendations in the sphere of financial risk management of agricultural entrepreneurship based on corporate social responsibility allow for the increase of only one component (out of four) of sustainable development of agriculture and food security-food quality and security. The directions of future research should be connected to the search for alternative measures of financial risk management of agricultural entrepreneurship, which will allow for a positive impact on the other three components of sustainable development of agriculture and food security: affordability, availability, natural resources, and resilience.

Author Contributions: Conceptualization, A.A.P. and V.I.P.; methodology, A.A.P. and V.I.P.; software, A.A.P. and V.I.P.; validation, A.A.P. and V.I.P.; formal analysis, A.A.P. and V.I.P.; investigation, A.A.P. and V.I.P.; resources, A.A.P. and V.I.P.; data curation, A.A.P. and V.I.P.; writing-original draft preparation, A.A.P.; writing-review and editing, V.I.P.; visualization, A.A.P.; supervision, V.I.P.; project administration, A.A.P. All authors have read and agreed to the published version of the manuscript.

Funding: This research received no external funding.

Conflicts of Interest: The authors declare no conflict of interest.

\section{Appendix A}

Table A1. Sample of 86 countries.

\begin{tabular}{|c|c|c|c|}
\hline $\mathbf{N}$ & Country & $\mathbf{N}$ & Country \\
\hline 1 & Algeria & 2 & Mali \\
\hline 3 & Argentina & 4 & Mexico \\
\hline 5 & Australia & 6 & Morocco \\
\hline 7 & Austria & 8 & Myanmar \\
\hline 9 & Bahrain & 10 & Nepal \\
\hline 11 & Bangladesh & 12 & Netherlands \\
\hline 13 & Belgium & 14 & New Zealand \\
\hline 15 & Benin & 16 & Nicaragua \\
\hline 17 & Bolivia & 18 & Nigeria \\
\hline 19 & Brazil & 20 & Norway \\
\hline 21 & Bulgaria & 22 & Pakistan \\
\hline 23 & Cambodia & 24 & Paraguay \\
\hline 25 & Cameroon & 26 & Peru \\
\hline 27 & Canada & 28 & Philippines \\
\hline 29 & Chile & 30 & Poland \\
\hline 31 & China & 32 & Portugal \\
\hline 33 & Colombia & 34 & Romania \\
\hline 35 & Congo (Dem. Rep.) & 36 & Russia \\
\hline 37 & Costa Rica & 38 & Saudi Arabia \\
\hline 39 & Côte d'Ivoire & 40 & Senegal \\
\hline 41 & Czech Republic & 42 & Serbia \\
\hline 43 & Denmark & 44 & Slovakia \\
\hline 45 & Dominican Republic & 46 & South Africa \\
\hline
\end{tabular}


Table A1. Cont.

\begin{tabular}{|c|c|c|c|}
\hline $\mathbf{N}$ & Country & $\mathbf{N}$ & Country \\
\hline 47 & Ecuador & 48 & Spain \\
\hline 49 & Egypt & 50 & Sri Lanka \\
\hline 51 & El Salvador & 52 & Sweden \\
\hline 53 & Ethiopia & 54 & Switzerland \\
\hline 55 & Finland & 56 & Tajikistan \\
\hline 57 & France & 58 & Tanzania \\
\hline 59 & Germany & 60 & Thailand \\
\hline 61 & Ghana & 62 & Tunisia \\
\hline 63 & Greece & 64 & Turkey \\
\hline 65 & Hungary & 66 & Uganda \\
\hline 67 & India & 68 & Ukraine \\
\hline 69 & Indonesia & 70 & United Arab Emirates \\
\hline 71 & Ireland & 72 & United Kingdom \\
\hline 73 & Israel & 74 & United States \\
\hline 75 & Italy & 76 & Uruguay \\
\hline 77 & Japan & 78 & Uzbekistan \\
\hline 79 & Jordan & 80 & Venezuela \\
\hline 81 & Kazakhstan & 82 & Vietnam \\
\hline 83 & Kenya & 84 & Yemen \\
\hline 85 & Malaysia & 86 & Zambia \\
\hline
\end{tabular}

\section{References}

Belhadi, Amine, Sachin Kamble, Venkatesh Mani, Imane Benkhati, and Fatima Ezahra Touriki. 2021. An ensemble machine learning approach for forecasting credit risk of agricultural SMEs' investments in agriculture 4.0 through supply chain finance. Annals of Operations Research, 1-29. [CrossRef] [PubMed]

Charities Aid Foundation. 2021. CAF World Giving Index 2021. Available online: https://www.cafonline.org/about-us/publications/ 2021-publications / caf-world-giving-index-2021 (accessed on 7 August 2021).

De Olde, Evelin M., and Vladislav Valentinov. 2019. The Moral Complexity of Agriculture: A Challenge for Corporate Social Responsibility. Journal of Agricultural and Environmental Ethics 32: 413-30. [CrossRef]

Diamantopoulos, Adamantios, and Heldi M. Winklhofer. 2001. Index Construction With Formative Indicators: An Alternative to Scale Development. Journal of Marketing Research 38: 269-77. [CrossRef]

Frascarelli, Angelo, Simone Del Sarto, and Giada Mastandrea. 2021. A New Tool for Covering Risk in Agriculture: The Revenue Insurance Policy. Risks 9: 131. [CrossRef]

Grabs, Janina, and Sophia Louise Carodenuto. 2021. Traders as sustainability governance actors in global food supply chains: A research agenda. Business Strategy and the Environment 30: 1314-32. [CrossRef]

Graddy-Lovelace, Garrett. 2021. Farmer and non-farmer responsibility to each other: Negotiating the social contracts and public good of agriculture. Journal of Rural Studies 82: 531-41. [CrossRef]

Hair, Joseph, Jr., William Black, Barry Babin, and Rolph Anderson. 2010. Multivariate Data Analysis: A Global Perspective, 7th ed. New York: Pearson.

Hajdu, Anna, Taras Gagalyuk, Eduard Bukin, and Martin Petrick. 2021. Determinants of Corporate Social Responsibility Among Farms in Russia and Kazakhstan: A Multilevel Approach Using Survey Data. International Food and Agribusiness Management Review 24: 697-716. [CrossRef]

Kang, Yunhee, Anurima Baidya, Alec Aaron, Jun Wang, Christabel Chan, and Erica Wetzle. 2021. Differences in the early impact of COVID-19 on food security and livelihoods in rural and urban areas in the Asia Pacific Region. Global Food Security 31 : 100580. [CrossRef]

Korolkova, Anna, Vitaliy Kuzmin, Tatiana Marinchenko, and Anna Goryacheva. 2020. Stimulating the Development of Breeding and Seed Production of Crops: Domestic and Foreign Experience: An Analytical Review. Moscow: Federal State Budgetary Scientific Institution "Rosinformagrotech".

Laskov, Valeriy. 2008. Self-regulation and regulation of agricultural planning in the region. Economist 5: 40-45.

MCX. 2021. Changes in Approaches to the Distribution of the "Single Subsidy" Are Being Prepared. Available online: http://mcx.ru/ press-service/news/gotovyatsya-izmeneniya-podkhodov-k-raspredeleniyu-edinoy-subsidii/ (accessed on 7 August 2021).

Mojtahedi, Fatameh, Seyed Mojtaba Mojaverian, Daniel Ahelegbey, and Paolo Giudici. 2020. Tail Risk Transmission: A Study of the Iran Food Industry. Risks 8: 78. [CrossRef]

Molitor, Fred, Celeste Doerr, and Sarah Kehl. 2021. Unemployment, SNAP Enrollment, and Food Insecurity Before and After California's COVID-19 Shutdown. Journal of Nutrition Education and Behavior 53: 1055-59. [CrossRef] [PubMed] 
Mukhopadhyay, Raj, Binoy Sarkar, Hanuman Sahay Jat, Parbodh Chander Sharma, and Nanthi Bolan. 2021. Soil salinity under climate change: Challenges for sustainable agriculture and food security. Journal of Environmental Management 280: 111736. [CrossRef]

Oubraham, Farid, Slimane Bédrani, and Fathi Abdellatif Belhouadjeb. 2021. Does interest rate subsidy really promote the financing of farms? The case of the wilaya of Laghouat in Algeria. Cahiers Agricultures 30. [CrossRef]

Pawlak, Karolina, and Malgorzata Kołodziejczak. 2020. The role of agriculture in ensuring Food security in developing countries: Considerations in the context of the problem of sustainable food production. Sustainability 12: 5488. [CrossRef]

Polukhin, Andrey, and Veronica Panarina. 2017. Seed production as the basis of Food security in the Russian Federation. Agricultural Economics of Russia 4: 55-59.

Popkova, Elena Gennadievna, and Bruno Sergio Sergi. 2021. Paths to the Development of Social Entrepreneurship in Russia and Central Asian Countries: Standardization Versus De-Regulation. Entrepreneurship for Social Change. Bingley: Emerald Publishing Limited, pp. 161-77. [CrossRef]

Popkova, Elena Gennadievna, Paper DeLo, and Bruno Sergio Sergi. 2020. Corporate Social Responsibility amid Social Distancing During the COVID-19 Crisis: BRICS vs. OECD Countries. Research in International Business and Finance 55: 101315. [CrossRef] [PubMed]

Qian, Xiaoyan, and Tava Lennon Olsen. 2021. Financial and risk management in agricultural cooperatives with application to the milk industry in New Zealand. International Journal of Production Research 59: 5913-43. [CrossRef]

Rosselkhoztsentr. 2021a. Rosselkhoztsentr Information Sheet No. 23. 2017. Available online: https://rosselhoscenter.com/ index.php/pressa/analitika/10615-informatsionnyj-listok-rosselkhoztsentra-23-2017-zaklyuchitelnaya-spravka-o-kachestvevyseyannykh-semyan-ynovyarovykh-zernobo-kultur-v-khozyajstvakh-rossijskoj-federatsii-v-2017-godu (accessed on 7 August 2021).

Rosselkhoztsentr. 2021b. Rosselkhoztsentr information Sheet No. 24. 2018. Available online: https://rosselhoscenter.com/index.php/ pressa/analitika (accessed on 7 August 2021).

Rosselkhoztsentr. 2021c. Register of seed farms of the Russian Federation FGBU "Rosselkhoztsentr". Available online: https: / / rosselhoscenter.com/index.php/2014-02-28-11-39-42/reestr-semenovodcheskikh-khozyajstv (accessed on 7 August 2021).

Rosselkhoztsentr. 2021d. Rosselkhoztsentr Information Sheet No. 21. 2020. Available online: https://rosselhoscenter.com/ (accessed on 7 August 2021).

Rosstat. 2021a. Acreage of the Russian Federation in 2016-2020. Available online: https://rosstat.gov.ru/compendium/document/13 277 (accessed on 7 August 2021).

Rosstat. 2021b. Gross Yield and Productivity of Crops in the Russian Federation in 2020. Available online: https://fedstat.ru/indicator/ 30950 (accessed on 7 August 2021).

Svitacova, Eva Pechociakova. 2021. Environmental responsibility in sustainable agriculture. Bulgarian Journal of Agricultural Science 27: 880-86.

Szczepankiewicz, Elżbieta Izabela. 2021. Identification of Going-Concern Risks in CSR and Integrated Reports of Polish Companies from the Construction and Property Development Sector. Risks 9: 85. [CrossRef]

Tang, Hondley, Zeeshan Rasool, Ahmad Imran Khan, Anum Afazl Khan, Moshin Ali Khan, and Ghalum Ahmad Azaz. 2021. The Impact of Private Standards on Corporate Social Responsibility Compliance and Rural Workers' Motivation in Developing Countries: A Study of Mango Farms in Pakistan. International Journal of Food Science. [CrossRef] [PubMed]

Ter-Grigoryants, Anna Aleksandrovna. 2010. The main directions of the strategy for the development of agriculture in the region. Bulletin of the North Caucasus State Technical University 2: 171-76.

The Economist Intelligence Unit Limited. 2021. The Global Food Security Report 2021. Available online: https:/ / foodsecurityindex.eiu. com/Country (accessed on 7 August 2021).

Tong, Zeping, and Shuo Yang. 2021. The Research of Agricultural SMEs Credit Risk Assessment Based on the Supply Chain Finance. E3S Web of Conferences 275: 01061. [CrossRef]

Vavrek, Roman, Ivana Kravčáková Vozárová, and Rastislav Kotulič. 2021. Evaluating the financial health of agricultural enterprises in the conditions of the slovak republic using bankruptcy models. Agriculture 11: 242. [CrossRef]

Volkenand, Steffen, Günther Filler, and Martin Odening. 2021. Price Discovery and Market Reflexivity in Agricultural Futures Contracts with Different Maturities. Risks 8: 75. [CrossRef]

Wang, Zhengjun, Junling Mu, and Yuehong Zheng. 2020. Construction of Farmer's Financing Mode under Internet Finance Embedded. Paper presented at 2020 International Conference on Big Data Economy and Information Management, BDEIM 2020, Zhenzhou, China, December 11-13; pp. 25-28. [CrossRef]

Budiasa, Wayan. 2020. Green financing for supporting sustainable agriculture in Indonesia. In IOP Conference Series: Earth and Environmental Science. Bristol: IOP Publishing, vol. 518, p. 012042. [CrossRef]

Zhang, Dehua. 2020. The Innovation Research of Contract Farming Financing Mode under the Block Chain Technology. Journal of Cleaner Production 270: 122194. [CrossRef]

Zhu, Bo, Renda Lin, Yuanyue Deng, Pingshe Chen, and Julien Chevallier. 2021. Intersectoral systemic risk spillovers between energy and agriculture under the financial and COVID-19 crises. Economic Modelling 105: 105651. [CrossRef] 